fore he had also demonstrated in the preparation of titanium carbide and other compounds that chemical combination took place at the highest temperatures at our command. What a technique! It is as if some master of the piano began at the base notes and swept up majestically to the highest treble!

Moissan studied particularly the chemistry of the elements. His isolation of calcium is a further example of new methods of attacking his favorite problem. At the International Congress at Berlin, he gave a lecture which charmed his audience and elicited the highest admiration. He presented his results on the hydrides of the alkalies and the alkaliearth metals. He added with these a further demonstration that hydrogen is not a metal, by showing that potassium and sodium hydrides, $\mathrm{KH}$ and $\mathrm{NaH}$, do not conduct electricity, and are therefore not alloys.

We find him passing readily from the realm of inorganic to that of organic chemistry, producing potassium formiate, HCOOK by the direct union of $\mathrm{KH}$ and $\mathrm{CO}_{2}$.

One can never read many pages of his memoirs without being struck with the fact that he made no sharp line of demarcation between the inorganic and the organic; to him they were but one chemistry.

With a host of collaborators Moissan was engaged to the last on a great work, 'Chimie Minerale.' A discourse given at the convocation of scientists at the St. Louis Exhibition in 1904, delivered at the invitation of the government, was a résumé of his introduction of this important treatise.

During the last few years Moissan had forged ahead. He was the president of the International Congress of Applied Chemistry in Paris in 1900. He had previously been appointed to Friedel's professorship at the Sorbonne, and with highest inspiration he was devoting his irrepressible energies to many problems. These were indeed multitudinous. His strictly scientific work was always paralleled with important applications for the well being of the human race. His originality showed him as a leader of thought and also a worker for his fellow beings, inaugurating new industries, planning new manufactures.
Few chemists have had wider influence. A medal struck in honor of the twentieth anniversary of the isolation of fluorine was only recently given him by his students and friends.

The recognition of all this was freely given to him not only at home, for France is loyal to her sons, but also abroad; the last highest honor conferred on him was the Nobel Prize, for chemistry, in 1906.

But to those who came within the subtle influence of his personality the fact that an operation for appendicitis, which resulted fatally on February 20, 1907, has severed a friendship with one whose charm of manner endeared him to students, associates and friends alike, has come as a blow so sudden and unexpected that it is difficult to fully realize it. Our sympathy goes out to his noble wife, that faithful amanuensis, who has indefatigably taken down the thoughts of the adored husband and preserved them for us, and to the young man, his only child, who is devoting himself to the same profession.

Resolved, That the New York Section of the American Chemical Society respectfully request the council of the society to fully recognize the esteem in which our honorary member, Henri Moissan, was held by tho members and associates of the society, and that appropriate resolutions be sent to his widow and son.

Charles G. Doremus

\section{JOHN KROM REES}

IT is the custom to mark the passing of a well-known man with a short notice of biography; and it is not difficult to recite a list of services, enumerate honors and distinctions conferred by public bodies, or recapitulate scientific researches and publications. But to the writer these things are cold and hard when said of Rees; to him Rees was known best as a friend-that rarest friendship whose beginning is outside the grasp of memory; whose end is a green sod.

Surely, if there exists a relation adapted better than any other to make one acquainted with the good or bad in any man, it is the relation of a subordinate to his chief. Dur- 
ing eighteen long years the writer sat at his work under Rees: in all that time there never came down to him an unkind word; never once did a serious difference of opinion arise. In eighteen years one becomes accustomed to any man; the few like Rees one comes to love. These words will fail signally in their purpose, if they do not convey to his sorrowing family such poor consolation as may come from those who feel and suffer with them.

Rees was but fifty-five on his last birthday; in his short life he had served Washington University as a professor five years, and $\mathrm{Co}^{-}$ lumbia University twenty-one. He had been president of the New York Academy of Sciences two years, and secretary of the American Metrological Society fourteen years. For six years he was secretary of the Columbia University Council. He was a fellow of the Royal Astronomical Society of London, a member of the Astronomische Gesellschaft of Leipzig, and in 1901 was created a chevalier of the Legion d'Honneur in recognition of his services as one of the judges at the Paris exposition in that year. His principal observational research was a study of the 'Variation of Terrestrial Latitudes and the Aberration of Light,' made at Columbia University, in cooperation with the Royal $\mathrm{Ob}$ servatory, Naples. This was the first application of the method of simultaneous observations at two stations situated on the same parallel of latitude, but separated widely in longitude. The work was continued from 1893 to 1900 : the method has since come into general use; and the International Geodetic Association, which includes all civilized governments, has now established four permanent stations to carry it on.

It was also during Rees's administration that the astronomical department of Columbia University undertook the publication of Rutherfurd's valuable series of star photographs. Through his efforts this enterprise was made possible; he took a keen interest in it, and spared no pains to further the work during a long series of years.

In educational matters Rees was at all times most active. His public lectures were fre- quent. Characterized especially by lucidity, they always attracted large audiences; people came to hear him again and again. But his most lasting contribution to educational development was his establishment of the Columbia summer school of geodesy. It is probable that he was the first to recognize practical field work in this subject as an indispensable adjunct in the training of civil engineers. Here he was at his best: his point of view always that of the genuine man of science, seeking ever the truth for its own sake; never exalting mere technique at the expense of theoretic perfection; never limiting his exposition of a subject to the side having most value from the financial point of view. Students frequently came back to him in later years; they always spoke of his summer school as the most agreeable memory of their college years. Whenever this occurred, Rees was a happy man for days.

At times Rees was persuaded to go beyond his quiet field of activity in the university. His most lasting public service to the nation was rendered as secretary of the Metrological Society, in furthering the introduction of standard or railroad time. The late Dr. F. A. P. Barnard, president of Columbia College, made the following reference to Professor Rees in his testament, dated 1886:

I give to my friend, Professor John Krom Rees, the watch known as my Cosmic Time Watch, as a mark of my regard and of my appreciation of his zealous efforts for the promotion of metrological reform and for the introduction of the now established system of public standard time.

Rees's attitude towards the scientific work of others was one of extraordinary modesty. To him the past masters of astronomy were not men; they were demi-gods, to be mentioned in respectful accents and with lowered tones. Even living visible masters of the craft commanded from him a degree of respect such as he could not have offered even to crowned royalties. His own work might be as good as theirs, but he could never see it so.

Another marked characteristic was his extreme delight when visited by any one to 
whom it was possible to do a favor.' This was his pleasure. No trouble was too great or time-consuming; no return, not even thanks, was expected. No man ever had fewer enemies: his friends equalled in number those who knew him. When at last the heary weight of disease was laid upon him he met it as a man should. No querulous repining: regret only that his work must stop; his solace that others would carry the good work on. Mother earth, that he loved well to measure and compute, will give him sleep; to him the peaceful end is surely a release.

\section{HAROLD J JCOBY}

\section{COMMISSION ON AGRICULTURAL RESEARCH}

AT the meeting of the Association of American Agricultural Colleges and Experiment Stations at Baton Rouge last November a resolution was adopted instructing the incoming president of the association to appoint a commission of five persons to inquire into and report to the association on the organization and policy that should prevail in the expenditure of public money provided for experimentation and research in agriculture. It was provided that two of these persons should represent the research efforts of the association; one the United States Department of Agriculture, and two the scientific men not connected with agricultural investigations. The president of the association, Dean L. H. Bailey, of Cornell University, has appointed the following commission, the first two representing persons outside agricultural investigations, the second two representing the association, and the last representing the Department of Agriculture: David Starr Jordan, president of Leland Stanford University, chairman; Carroll D. Wright, president of Clark College; H. P. Armsby, director Pennsylvania State College Agricultural Experiment Station; W. H. Jordan, director of the New York State Experiment Station; Gifford Pinchot, forester, U. S. Department of Agriculture.
SEVENTH INTERNATIONAL CONGRESS OF PHYSIOLOGISTS

THE seventh International Physiological Congress will be held under the presidency of Professor A. Kossel in the Physiological Institute of the University of Heidelberg August $13,14,15$ and 16.

Titles of papers and an exact list of apparatus or other articles required for demonstrations should be sent to the Physiological Institute at Heidelberg not later than June 15.

From August 12 to August 17 there will be held an exhibition of apparatus, by members of the congress, directors of physiological institutes and mechanics recommended by members or directors.

The official languages are French, German, Italian and English. The general secretaries are Professors Dastre (Paris), Fano (Florence), Grützner (Tübingen), Porter (Boston) and Sherrington (Liverpool).

\section{THE OENTRAL BRANCH OF THE AMERICAN SOCIETY OF NATURALISTS}

There will be held at the University of Wisconsin, Madison, Wis., on March 28, 29 and 30,1907, meetings of the Central Branch of the American Society of Naturalists in affiliation with the Central Branch of the American Society of Zoologists, the Association of American Anatomists and the Central Branch of the American Society of Botanists. Each of these societies have an interesting program of papers and demonstrations. Papers will be read during the morning sessions on March 28 and 29 and demonstrations will be given in the afternoons. On Thursday evening, March 28, there will be a smoker for the affiliated societies and on Friday evening a dinner of the Naturalists and affiliated societies, at which time the address of the president of the Central Branch of Naturalists will be given by Professor J. Playfair McMurrich, of the University of Michigan.

\section{SCIENTIFIC NOTES AND NEWS}

LORD LisTer will celebrate his eightieth birthday on April 4, and it is proposed that to mark this event his scientific papers be col- 